\title{
Morphology of secondary calcite deposits in an abandoned mine in the Western Rhodopes, Bulgaria
}

\section{Морфология на вторични калцитови образувания в изоставена мина в Западни Родопи, България}

\author{
Eugenia Tarassova ${ }^{1}$, Mihail Tarassov ${ }^{1}$, Alexey Zhalov', Zhivka Janakieva ${ }^{3}$ \\ Евгения Тарасова ${ }^{1}$, Михаил Тарасов', Алексей Жалов², Живка Янакиева ${ }^{3}$ \\ ${ }^{1}$ Institute of Mineralogy and Crystallography, Bulgarian Academy of Sciences, Sofia; E-mail: etarassova@mail.bg \\ ${ }^{2}$ Balkan Speleological Union \\ 3 "Earth and Man" National Museum, Sofia
}

\begin{abstract}
Caps and pearls are the most common morphology types of secondary calcite deposits in the abandoned mine gallery built in gneisses. Their formation is associated with the infiltration into the gallery of rainwater from the overlying marbles. The formation mechanism and morphology of these secondary calcite deposits are identical to those typical for cave caps and pearls.
\end{abstract}

Keywords: secondary calcite deposits, caps, pearls, mine, Bulgaria.

\section{Introduction}

During the infiltration of crack water into mine galleries, secondary calcite deposits can crystallize which are morphologically identical to speleothems formed in caves. Like speleothems in caves, the intensity and cyclicity of crystallization of these secondary deposits depend on the hydrogeological, climatic and geological conditions in the region. According to Hill and Forti $(1995,1997)$, despite the similarity of morphology, mineral composition, and crystallization mechanism, the secondary calcite deposits formed in "artificial caves" cannot be regarded as speleothems, since they do not form in natural caves. This paper presents the results of studying the morphology of the most common and impressive secondary calcite deposits from an abandoned mine gallery in the Western Rhodopes, near the town of Velingrad.

\section{Historical background and geological setting}

In 1954-1956, about $10 \mathrm{~km}$ southeast of the town of Velingrad, a mine gallery $198 \mathrm{~m}$ long was built by „Rare Metals“ State Company for the purpose of exploration and prospecting for uranium, which was soon abandoned. The gallery is built in twomica gneisses with pegmatite veins over which marbles lie. The area belongs to the NE periphery of the Velingrad karst region. The karst system is developed in a layer of marble $35 \mathrm{~km}$ long, up to $3 \mathrm{~km}$ wide and no more than $200 \mathrm{~m}$ thick. The marbles are strongly karstified. There are several caves in them, the largest of which is the three-storey water cave "Lepenitsa" with a length of 1525 $\mathrm{m}$. Numerous springs are associated with the karst water system, including the Kleptuza spring in Velingrad (Kerekov, Manchev, 1959). The development of karst is determined by the climatic conditions and the high seismic and tectonic activity of the region (Shanov, Kostov, 2015; Kostov, Ostromsky, 2021). The marbles are white, medium- and single-grained, and contain interlayers of gneisses and schists with a thickness of several tens of meters (Kerekov, Manchev, 1959). The mineral composition of marbles is dominated by calcite and little graphite. The marbles belong to the high-grade metamorphic complex of the Chepino Unit which consists of biotite and two mica gneisses, amphibolites, 
schists and marbles. All the rocks were affected by high-temperature amphibolite facies metamorphism and migmatization processes which are associated with numerous pegmatoid and aplitoid veins (Sarov et al., 2008).

\section{Material and methods}

Selected specimens from a collection of secondary calcite deposits from the abandoned mine gallery stored in the National Museum "Earth and Man" were studied in the present work. The sampling place is $15-50 \mathrm{~m}$ from the entrance of the gallery. The specimens were examined using optical microscopy (OM) (Leitz-Orthoplan, IMC-BAS), scanning electron microscopy (SEM) (ZEISS SEM EVO 25LS with an EDAX Trident system, IMCBAS) and powder X-ray diffraction (XRD) analysis (PANanalytical EMPYREAN Diffractometer system, IMC-BAS).

\section{Morphology of secondary calcite deposits}

The main processes determining the formation of secondary calcite deposits are crystallization and dissolution. (Fig. 1k, i, j). These processes are cyclical and depend on seasonal hydrogeological and climatic conditions. For a short life (about 65 years), several morphological types of secondary calcite deposits have formed and continue to form
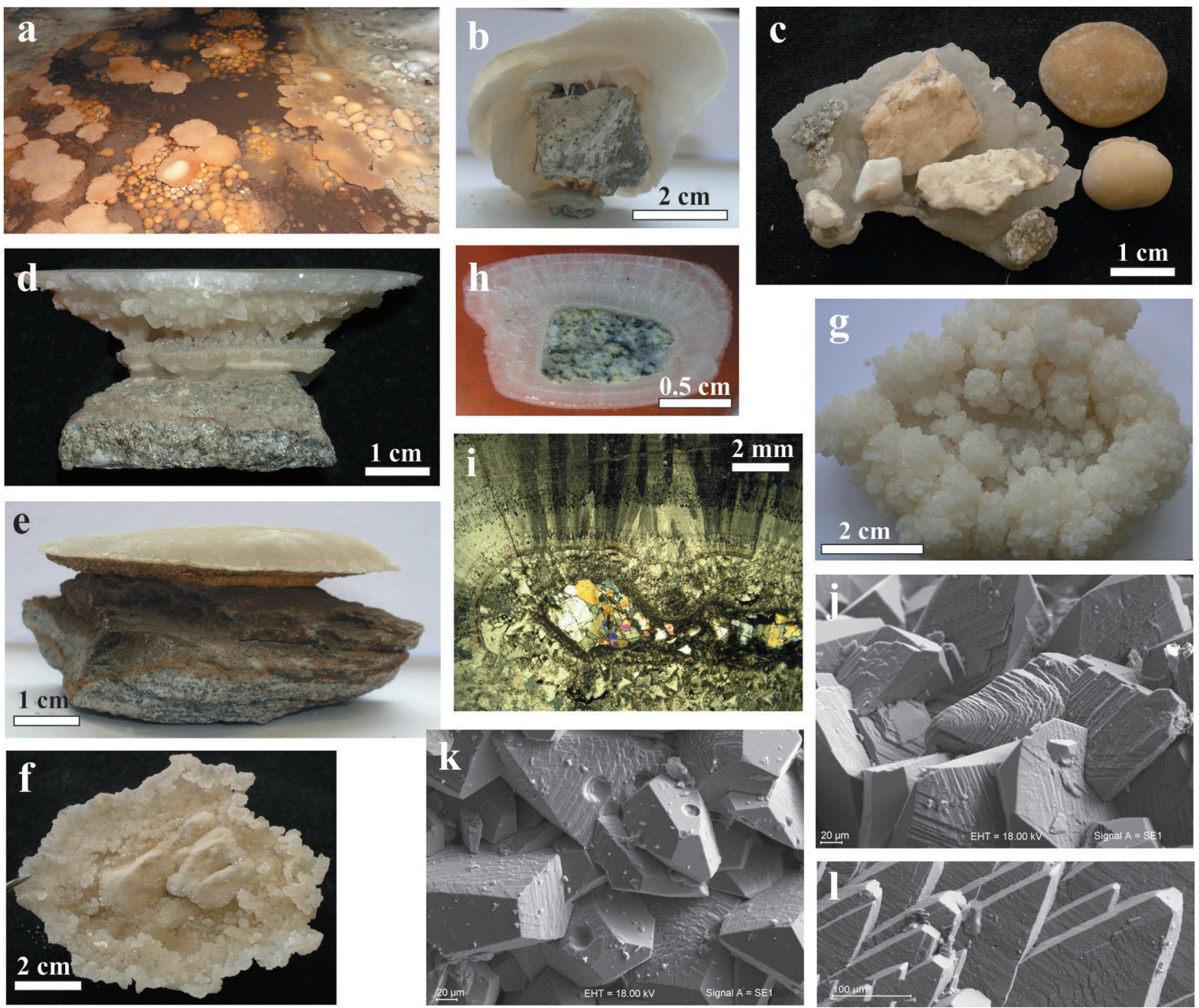

Fig. 1. $a$, secondary calcite deposits on the floor of the mine gallery - pearls and caps; $b$, triple cap overgrows a piece of gneiss; $c$, cap grew on pieces of pegmatite and gneiss. On the right there are two pearls with a sugar-like surface; $d$, double caps on a piece of gneiss. Alternation of crystallization and dissolution processes; $e$, cap growing on a gneiss fragment; $f$, A cap on the periphery of which calcite dendrites grow; $g$, calcite druse; $h$, cross-section of a pearl with a gneiss core; $i$, cross section of a pearl. Concentric zonal structure around the gneiss core - fine-grained calcites first crystallize around the cores, which are then overgrown with radial-fibrous calcite (OM image); $j$, dissolution of calcite crystals caused by falling water droplets (SEM); $k$, micro sculpture of calcite crystals caused by crystallization-dissolution process (SEM); $l$, calcite crystals (SEM). 
in the gallery. Simple forms are common, such as caps, pearls, pendants, subaqueous moonmilk, rafts, calcite druse (Fig. 1g), and others. The most widespread and attractive morphological types are caps (Fig. 1b-f) and pearls (Fig. 1c).

Caps are 5-15 cm in size. They are formed on the floor of the gallery. They look like caps that cover the tops of small pieces of gneisses, pegmatites, and pearls on mine floor. As the size increases, the caps begin to grow together. There are also caps that grow on top of each other (Fig. 1b) as a result of seasonal interruptions in the supply of feed water. In caves such caps are rare speleothems (Hill, Forti, 1997). According to these authors, cave caps are formed by dripping water. It covers the pebbles lying on the floor with fine capillary water, from which, reaching the upper parts of the pebbles, where the conditions are drier, crystallization of calcite begins.

Pearls are 1-5 cm in size. They form at the bottom of a shallow puddle, where water slowly drips or flows in trickles from the walls of the gallery. They are not fixed and form fields on the floor of the mine. They are concentrically banded concretion with spherical to irregular shape with nuclei presented by particles of bedrocks - gneisses and pegmatites (Fig. 1a, c, h, i). Calcite, crystallized in solution, is deposited on the debris by gravity and then the concentric growth begins. When the water drips, the pearls vibrate and can grow without stirring the water. Their color is white, beige to brown. Their coloration is due to the inclusion of clay particles trapped during growth. The outer surface of some pearls is smooth, and on others it is overgrown with calcite crystals. For pearls is typical a combination of radial fibrous and concentric-zonal structures (Fig. 1i). Pearls are one of the most common speleothems in caves. In the saturated solutions in the shallow cave pool environment, many differently oriented crystals crystallize on the rock fragments. After geometric selection, only those crystals continue to grow, which are oriented in the direction of the highest growth rate of the pearl radius (Grigor'ev, 1961).

SEM and XRD studies of caps and pearls show that calcite is the predominant mineral in these deposits. The brownish color of some of them is due to the inclusion of clay particles.

\section{Conclusions}

The most common morphological types of secondary calcite deposits that have been formed and continue to form in the abandoned mine near Velingrad are caps and pearls. They are found together on a wet mine floor or in shallow puddle. Particles of rocks are involved in their structure: caps are formed around them, while in the structure of pearls they play the role of nuclei. Crystallization of secondary calcite deposits is an example of modern low-temperature mineral formation. Although they form in an artificial cavity and not in a karst cave, they are striking in their beauty and attractiveness and therefore they deserve proper protection from human impact. Their formation in the mine gallery is an example of how nature erase traces of human intervention and create new natural equilibria.

Acknowledgements: The authors acknowledge the technical support from the project PERIMED BG05M2OP001-1.002-0005 /29.03.2018 (20182023).

\section{References}

Grigor'ev, D. P. 1961. Ontogenia Mineralov. Lviv University Publishing House, 284 p. (in Russian)

Hill, C. A., P. Forti. 1995. The classification of cave minerals and speleothems. - J. Speleol. (Phys.), 1-4, 77-82; http:// dx.doi.org/10.5038/1827-806X.24.1.5

Hill, C. A., P. Forti. 1997. Cave Minerals of the World (2nd ed.). Huntsville, Alabama, National Speleological Society, $463 \mathrm{p}$.

Kerekov, S., P. Manchev. 1959. The karst waters between Beglika and Velingrad. - In: Karst Groundwater in Bulgaria. Sofia, Tehnika, 85-93 (in Bulgarian).

Kostov, K., Tz. Ostromsky. 2021. Traces of palaeoseismic activity in Lednika cave, West Rhodopes Mts, South Bulgaria. - Rev. Bulg. Geol. Soc., 82, 3, 242-244; https://doi. org/10.52215/rev.bgs.2021.82.3.242.

Sarov, S., E. Voinova, I. Georgieva, D. Nikolov, K. Naidenov, N. Petrov, N. Markov, R. Marinova. 2008. Explanatory note to the Geological Map of the Republic Bulgaria, Scale 1:50 000. Map Sheet K-34-72-G (Velingrad). Sofia, Ministry of Environment and Water, Bulgarian Geological Survey, $32 \mathrm{p}$.

Shanov St., K. Kostov. 2015. Dynamic Tectonics and Karst. Berlin Heidelberg, Springer-Verlag, 123 p.; https://doi. org/10.1007/978-3-662-43992-0. 